\title{
Virus Assessment of Ajuga reptans Cultivars Reveals Alfalfa Mosaic, Tobacco Streak, and Cucumber Mosaic (CMV) Viruses, and a CMV Satellite RNA
}

\author{
J.R. Fisher ${ }^{1}$ and S.T. Nameth ${ }^{2}$ \\ Department of Plant Pathology, The Ohio Agricultural Research and \\ Development Center, Columbus, $\mathrm{OH} 43210$
}

Additional index words. reverse transcription polymerase chain reaction (RT-PCR)

\begin{abstract}
Ajuga reptans L. is an herbaceous ornamental mint grown in borders or as a groundcover, and is commonly propagated vegetatively and by seed. Three hundred and fifty-six A. reptans samples were obtained from growers in Washington, Michigan, Iowa, and Ohio, and screened for alfalfa mosaic virus (AMV), tobacco streak ilarvirus (TSV), cucumber mosaic cucumovirus (CMV), tomato aspermy cucumovirus (TAV), tomato spotted wilt tospovirus (TSWV), impatiens necrotic spot tospovirus (INSV), tobacco mosaic tobamovirus (TMV), potato virus $X$ potexvirus (PVX), and 80 potyviruses, using direct antibody sandwich (DAS) and indirect enzyme-linked immunosorbent assay (ELISA). Viral-associated double-stranded ribonucleic acid (dsRNA) analysis was used to detect an apparent satellite (sat) RNA, and northern hybridization using a digoxigenin (DIG) labeled (S) CARNA-5 cDNA probe was used to confirm the identity of the apparent satRNA. No incidences of TAV, TMV, TSWV, INSV, PVX, or potyviruses were detected. CMV was detected in $11 \%$, AMV in $22.2 \%$, TSV in $3.7 \%$, and mixed infections of CMV and AMV in $1.1 \%$ of the samples. SatRNA was detected in 36 A. reptans 'Royalty', two 'Rainbow', and two 'Burgundy Glow' samples by dsRNA analysis, and confirmed by hybridization in 29 'Royalty' and one 'Burgundy Glow' samples. Sixteen A. reptans 'Royalty' seedlings grown from seed harvested from CMV-infected plants were tested by ELISA for CMV, AMV, and TSV. All were positive for CMV, and two were positive for a mixed infection of CMV and AMV. SatRNA was detected in all 16 seedlings by RT-PCR.
\end{abstract}

Ajuga reptans $\mathrm{L}$. is a perennial ornamental mint (Lamiaceae) grown in borders or as a groundcover. Cultivars include 'Bronze Beauty', 'Burgundy Glow', 'Royalty', 'Rainbow', 'Silver Beauty', and 'Catlin's Giant', and are commonly propagated vegetatively and by seed. Cucumber mosaic cucumovirus (CMV), alfalfa mosaic virus (AMV), tobacco streak ilarvirus (TSV) and broad bean wilt fabavirus (BBWV) were reported in this host in Australia (Shukla and Gough, 1983), CMV in Denmark (Kristensen, 1956), and AMV in the United States (Schroeder and Provvidenti, 1972). Recently CMV, AMV, and TSV were reported in A. reptans cultivars in Ohio, and a satRNA was also found to be associated with CMV-infected A. reptans 'Royalty' plants (Fisher and Nameth, 1997).

Received for publication 15 Mar. 1999. Accepted for publication $31 \mathrm{Aug}$. 1999. This paper is a portion of a thesis submitted by J.R. Fisher toward the completion of the requirements of the $\mathrm{PhD}$ degree in Plant Pathology. Salaries and research support provided by state and federal funds appropriated to the Ohio Agricultural Research and Development Center, Ohio State Univ. The cost of publishing this paper was defrayed in part by the payment of page charges. Under postal regulations, this paper therefore must be hereby marked advertisement solely to indicate this fact.

${ }^{1}$ Graduate Research Assistant.

${ }^{2}$ Associate Professor; to whom reprint requests should be addressed (e-mail: Nameth.2@osu.edu).
CMV, TSV, and AMV are single-stranded RNA viruses belonging to the family Bromoviridae. All three contain three major genome segments, and have very wide host ranges (Francki et al., 1979; Fulton, 1985; Jaspars and Bos, 1980). The AMV is transmitted mechanically, through seed, and by 24 species of aphids in the nonpersistent manner (Edwardson and Christie, 1991; Jaspars and Bos, 1980). The TSV is transmitted mechanically, through seed, and by at least two thrips species [Frankliniella occidentalis (Pergande) and Thrips tabaci Lindeman] (Fulton, 1985), and CMV is transmitted mechanically, through seed, and by $>60$ aphid species in the nonpersistent manner (Francki et al., 1979). Many CMV isolates also have an additional satellite RNA (satRNA) associated with them. This satRNA is dependent upon the helper virus for replication and encapsidation, often interferes with the replication of the helper virus, and affects symptoms induced by the helper virus (Collmer and Howell, 1992). The effects on symptom expression produced by the presence of satRNA are influenced by the strain of CMV, the host plant, and the satRNA strain. For example, symptoms on tomato (Lycopersicon esculentum Mill.) plants containing satRNA can range from lethal necrosis, to white chlorosis, to disease attenuation, depending on the satRNA strain (Collmer and Howell, 1992). However, the same satRNA strain can have different effects on tomato and tobacco (Nicotianum sp.). The CMV white leaf (WL) strain plus a particular satRNA produces a white leaf syndrome on tomato. On tobacco, the CMV-WL genomic RNAs produce a brilliant chlorosis, but the addition of the satRNA causing white leaf in tomato leads to a symptomless infection (Gonsalves et al., 1982). The CMV satRNAs can also be helped by the related tomato aspermy cucumovirus (TAV) (Collmer and Howell, 1992).

In this paper we report the results of a serological screening of $A$. reptans cultivars for CMV, AMV, TSV, TAV, tomato spotted wilt tospovirus (TSWV), impatiens necrotic spot tospovirus (INSV), tobacco mosaic tobamovirus (TMV), potato virus X potexvirus (PVX), and a potyvirus screen. Ajuga reptans samples were obtained from growers in the United States and screened for viral infection using the enzyme-linked immunosorbent assay (ELISA).

\section{Materials and Methods}

Plantmaterial. Samples were obtained from growers in the states of Washington, Michigan, Iowa, and Ohio. Growers were requested to send plants typical of their stock, but any plants displaying symptoms were of special interest. Additionally, samples were collected from several established plantings in Ohio. A total of 356 samples were tested for all nine viruses. Live plants were transplanted and maintained in the greenhouse for the project duration and symptoms were noted prior to ELISA testing. Established plantings were surveyed for virus-like symptoms such as mosaic and ringspots, and samples of the symptomatic plants were collected. If no symptoms were evident then asymptomatic tissue was collected. Freshly collected tissue was prepared immediately for direct antibody sandwich (DAS) ELISA.

DAS and indirect ELISA. Samples were tested using a variation of the method previously described (Clark and Adams, 1977). Commercially produced antibodies (AGDIA, Elkhart, Ind.) against CMV, AMV, TSV, TAV, TSWV, INSV, TMV, and PVX were used in this study, as well as an indirect ELISA potyvirus screen that tests for 80 potyviruses. Asymptomatic, apparently virus-free, $A$. reptans 'Bronze Beauty' tissue collected from an established planting was used as negative control after first testing against all of the antisera using extraction buffer as the negative control. In all cases, the average absorbance of two wells was similar to that of the extraction buffer control (i.e., 0.07 for the healthy tissue vs. 0.08 for the extraction buffer). A healthy tissue negative control and an extraction buffer negative control were included in each plate. The same negative control tissue was used for the project duration. Tissue known to be positive for the above viruses was used as positive control. Tissue positive for watermelon mosaic virus I was used as a positive control for the potyvirus screen. Since AMV and TSV are distantly related (Jaspars and Bos, 1980), the AMV and TSV positive controls were crossabsorbed with each other's antisera to be cer- 
tain false positives were not obtained due to cross-reactivity. Nunc Maxisorp 96 well polystyrene microtitre plates (Thomas Scientific, Swedesboro, N.J.) were used in the study. Each sample was dispensed into two test wells, and the average absorbance of the two wells at $405 \mathrm{~nm}$ was determined using a microtitre plate reader(EAR 400SFPlus EIA plate reader; SLT Lab Instruments, Hillsborough, N.C.). A sample was considered to be positive if its absorbance was twice that of the negative control value established for that plate.

Viral dsRNA analysis. Viral-associated double-stranded ribonucleic acid (dsRNA) was extracted and purified as previously described (Jordan et al., 1983; Morris and Dodds, 1979). DsRNA was loaded onto $5 \%$ or $10 \%$ polyacrylamide gels and analyzed by electrophoresis. Ethidium bromide-stained dsRNA bands were visualized on a transilluminator $(302 \mathrm{~nm})$ and photographed with Polaroid-type 667 black and white film.

Northern hybridization. Following extraction and purification, dsRNA was heat denatured, subjected to electrophoresis, and blotted onto positively charged nylon membranes (Boehringer Mannheim, Indianapolis) as previously described (Sambrook et al., 1989). Molecularly cloned (S)CARNA-5 (-) cDNA (ATCC \# 45124) was labeled with digoxigenin (DIG) as per the manufacturer's instructions (Genius II DIG-DNA Labeling Kit, Boehringer Mannheim) and used as a diagnostic probe to detect satRNA. Hybridization was performed at $68^{\circ} \mathrm{C}$, and two highstringency washes were performed in $0.1 \times$ SSC buffer $(0.0015 \mathrm{M}$ sodium citrate, $0.015 \mathrm{M}$ $\mathrm{NaCl}, 0.1 \%$ w/v SDS) at $68{ }^{\circ} \mathrm{C}$.

Reverse transcription polymerase chain reaction (RT-PCR). Two pairs of primers were designed for RT-PCR detection of satRNA in A. reptans by comparing 10 previously published satRNA sequences. The published satRNA sequences used were GsatRNA，B1-satRNA，B2-satRNA，B3satRNA, WL1-satRNA, WL2-satRNA (Garcia-Arenal et al., 1987), E-satRNA, OYsatRNA (Hidaka et al., 1988), Y-satRNA (Hidaka et al., 1984) and D-satRNA (Kurath and Palukaitis, 1987). The primer sequences 5'-GTTTTGTTTGTTAGAGAACTG-3', which hybridizes to the 3 ' end of minus-sense satRNA, and 5'-GGAGATGGTCCTGGG-3', which hybridizes to the 3' end of positivesense satRNA, were used to reverse transcribe full length cDNAs. The primer sequences 5'GTTTGATGGAGAACTGCGTAGAG-3' and 5'-CAGATGTGTAAGGAGATGGTC-3', which were nested five bases inward from the 5' and 3' ends, respectively, of the full-length satRNA molecule, were used in the PCR amplification. Samples were prepared by grinding tissue at a 1:4 ratio in $1 \times$ TBST buffer $(0.025 \mathrm{M}$ tris, $\mathrm{pH} 8.0 ; 0.015 \mathrm{M} \mathrm{NaCl} ; 0.05 \% \mathrm{v} / \mathrm{v}$ Tween-20). The macerate was placed in 1.5$\mathrm{mL}$ microcentrifuge tubes, and centrifuged at $11,500 g_{s}$ in a benchtop microcentrifuge for 10 min, and the supernatant further diluted to 1:16 and 1:32 in TBST buffer. A two-step RTPCR reaction was performed as previously described (Innis et al., 1990). The RT reaction was performed in a $20-\mu \mathrm{L}$ volume with $1 \mu \mathrm{L}$ each of $0.1 \mu \mathrm{g} \cdot \mu \mathrm{L} 3^{\prime}$ and 5 ' primer, $3 \mu \mathrm{L}$ 1:16 or 1:32 sap extract, and 200 units Superscript II (Gibco, BRL Inc., Gaithersburg, Md.) reverse transcriptase and incubated at $42^{\circ} \mathrm{C}$ for $1 \mathrm{~h}$. One-tenth volume $(2 \mu \mathrm{L})$ of the RT reaction was used in the PCR reaction, which was done in a $50-\mu \mathrm{L}$ volume with $4 \mathrm{~mm} \mathrm{MgCl}_{2}, 0.1$ $\mu \mathrm{g}$ each 3 ' and 5' primer, and 2.5 units Taq polymerase (Gibco, BRL Inc.). Thirty cycles were performed $\left(94{ }^{\circ} \mathrm{C}\right.$ denaturation; $52{ }^{\circ} \mathrm{C}$ primer annealing; $72{ }^{\circ} \mathrm{C}$ extension), and onehalf volume of the reaction was analyzed on a $1.5 \%$ agarose gel. Tissue known to be positive for CMV and satRNA was used as positive control in the $\mathrm{RT}$ reaction and $\mathrm{ddH}_{2} \mathrm{O}$ or TBST buffer used as negative control.

Inoculation of test plants. Nicotiana rustica L. and N. tabacum 'Glurk', 'Turk', and 'Samsun' were rub-inoculated using one of the symptomatic 'Royalty' and 'Rainbow' plants as the source of inoculum. Tissue was ground at a $1: 10$ ratio in $0.02 \mathrm{M}$ sodium phosphate buffer $(\mathrm{pH} 7.0)$ containing $0.1 \%(\mathrm{w} / \mathrm{v})$ thioglycollic acid. Five plants of each variety were inoculated, and one plant of each variety was rubbed with only buffer as a negative control. The inoculum or buffer was rinsed off after $5 \mathrm{~min}$ to avoid phytotoxicity. The plants were kept in the greenhouse and observed for symptoms over the next $90 \mathrm{~d}$. Symptomatic plants for CMV, AMV, and TSV were tested by ELISA.

CMV-infected 'Royalty' plants were allowed to produce seed and the resulting seedlings at the four-leaf stage were tested by ELISA for CMV, AMV, and TSV.

\section{Results}

Symptoms observed on A. reptans plants were similar to those previously described (Shukla and Gough, 1983). Red and yellow spots, ringspots, mosaic, and oakleaf patterns developed on 'Bronze Beauty' (Fig. 1A). Symptoms on 'Burgundy Glow', which normally has pink, green, and white variegated leaves, included yellow streaks, mosaic and oakleaf-like patterns (Fig. 1B). Several samples of the cultivar 'Rainbow' showed severe mosaic and ringspots (Fig. 1D). Some 'Royalty' plants displayed red, orange, or yellow spots, and ringspots (Fig. 1C), but the majority of 'Royalty' plants were asymptomatic.

None of the 356 A. reptans plants were positive for TAV, TMV, TSWV, INSV, PVX, or the potyvirus screen. Thirty-nine samples were positive for CMV (11\%), 13 for TSV (3.7\%), 79 for AMV (22.2\%), and four $(1.1 \%)$ for a mixed infection of CMV and AMV, using the criterion described above for determining positive results. Several samples had elevated absorbance values that were not high enough to be considered positive, but were clearly higher than the established negative control values. Thirty-eight samples $(10.7 \%)$ had elevated absorbance values for AMV, one (2.7\%) for CMV, and $18(5.0 \%)$ for TSV. No incidences of a mixed infection of AMV and TSV, or of CMV and TSV, were detected. A summary of the overall ELISA data for CMV,
AMV, and TSV is presented in Table 1. In some cases, positive results were obtained from asymptomatic plants, or samples collected from plants showing mosaic or ringspot symptoms were negative in all tests. These results are also summarized in Table 1.

Each of 16 seedlings grown from seed collected from CMV-infected 'Royalty' plants was positive for CMV by ELISA. Additionally, two of $16(11.8 \%)$ were positive for a mixed infection of CMV and AMV, but none of the seedlings was positive for TSV. Only two of the 16 seedlings showed a slight mosaic symptom at the time of testing. One of the symptomatic seedlings was positive for CMV, and the other for CMV and AMV. All of the others remained symptomless over the next $60 \mathrm{~d}$.

DsRNA analysis of symptomatic and asymptomatic 'Royalty' tissue, and of symptomatic 'Rainbow' tissue, produced a banding pattern consistent with infection by CMV and an associated satRNA (Dodds et al., 1984; Valverde et al., 1990) (Fig. 2). The apparent satRNA was present in all 36 'Royalty' samples tested and both 'Rainbow' samples tested. In addition, double stranded satRNA was detected in two of the three 'Burgundy Glow' samples with a mixed infection of CMV and AMV. The identity of the apparent satRNA was confirmed by hybridization to the (S)CARNA-5 probe in 29 of the 'Royalty' samples (Fig. 3). One of the 'Burgundy Glow' samples showing double stranded satRNA was probed and it reacted faintly (data not shown). The remaining seven 'Royalty' and two 'Rainbow' samples were not tested by hybridization. All 16 'Royalty' seedlings that were ELISA-positive for CMV were assayed for the presence of satRNA using RT-PCR. A PCR product corresponding to the satRNA was detectable in all (Fig. 4). The identity of the PCR products was confirmed by hybridization to the DIG-labeled (S)CARNA-5 probe (not shown).

Nicotiana rustica, mechanically inoculated with 'Royalty' and 'Rainbow' sap, never developed symptoms. N. tabacum 'Glurk', 'Turk', and 'Samsun' inoculated with 'Royalty' sap all developed similar symptoms ranging from mild mosaic to ringspots to oakleaf to a systemic line pattern. The line pattern and ringspots were more prevalent on older leaves and often disappeared, while the mosaic and oakleaf were more prevalent on younger leaves. Nicotiana tabacum 'Glurk', 'Turk', and 'Samsun' inoculated with 'Rainbow' sap developed symptoms similar to those observed on the plants inoculated with 'Royalty' sap. When tested by ELISA for CMV, AMV, and TSV, several symptomatic 'Turk' plants inoculated with 'Royalty' sap and several 'Samsun' inoculated with 'Rainbow' sap were positive for CMV. However, the majority of the tobacco plants showing symptoms were negative for all three viruses. DsRNA analysis of 'Glurk' inoculated with 'Rainbow' sap, and showing line pattern symptoms, produced several faint bands. DsRNA analysis of 'Samsun' inoculated with 'Rainbow' sap, also showing line pattern, produced a CMV-like banding 


\section{Plant Pathology}
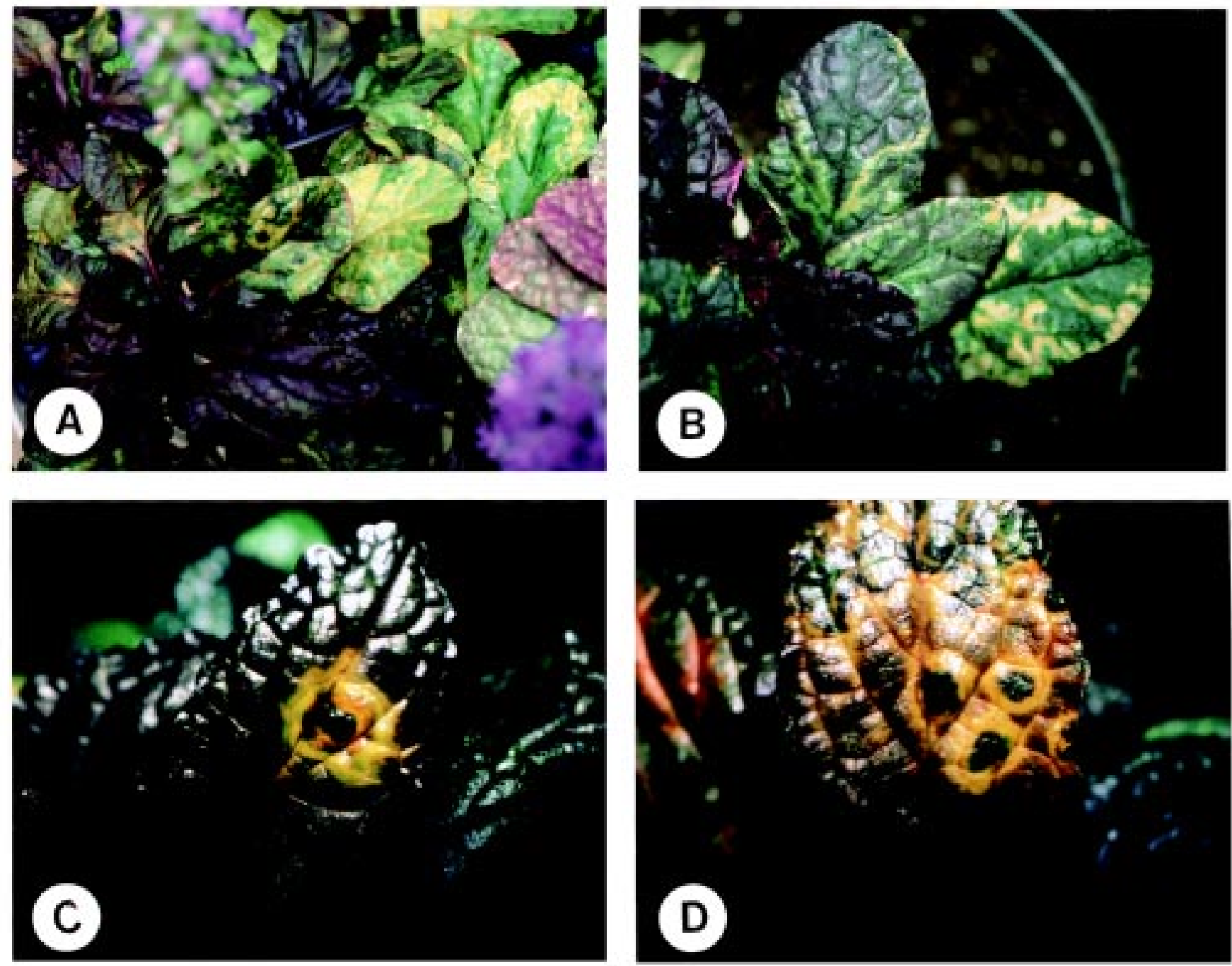

Fig. 1. Virus-induced symptoms observed on Ajuga reptans cultivars. (A) ‘Bronze Beauty', (B) 'Burgundy Glow', (C) ‘Royalty', and (D) ‘Rainbow'.

Table 1. Summary of symptomatic and asymptomatic Ajuga reptans cultivars tested for CMV, AMV, and TSV, by ELISA.

\begin{tabular}{|c|c|c|c|c|c|c|c|c|c|c|}
\hline \multirow{2}{*}{ Cultivar $^{2}$} & \multirow{2}{*}{ No. tested } & \multicolumn{9}{|c|}{ No. of plants ${ }^{\mathrm{x}}$} \\
\hline & & Total & \multicolumn{4}{|c|}{ With symptoms ${ }^{y}$} & \multicolumn{4}{|c|}{ Without symptoms } \\
\hline$\overline{\mathrm{BB}}$ & 189 & $88(47)$ & 0 & $22(12)$ & 0 & $10(5)$ & 0 & $11(6)$ & $8(4)$ & $32(17)$ \\
\hline ROY & 36 & $6(17)$ & $35(97)$ & 0 & 0 & 0 & $29(81) 0$ & 0 & 0 & \\
\hline $\mathrm{RB}$ & 2 & 2 & $2(100)$ & 0 & 0 & 0 & 0 & 0 & 0 & 0 \\
\hline GR & 35 & 2 & 0 & $22(63)$ & 0 & $3(9)$ & 0 & $20(57)$ & $3(9)$ & 0 \\
\hline GTY & 24 & 0 & $1(4)$ & $5(21)$ & 0 & 0 & $1(4)$ & $5(21)$ & 0 & 0 \\
\hline CG & 7 & $4(57)$ & 0 & $1(14)$ & 0 & 0 & 0 & 0 & 0 & $4(57)$ \\
\hline MCR & 4 & 0 & 0 & 0 & 0 & 0 & 0 & 0 & 0 & 0 \\
\hline $\mathrm{AG}$ & 2 & 0 & 0 & 0 & 0 & 0 & 0 & 0 & 0 & 0 \\
\hline Total & 356 & 107 & 39 & 79 & 4 & 13 & 30 & 62 & 11 & 36 \\
\hline$\%$ of Total & & 30 & 11 & 22 & 1.1 & 4 & 8 & 17 & 3 & 10 \\
\hline
\end{tabular}

${ }^{2}$ A. reptans cultivar abbreviations: $\mathrm{BB}=$ Bronze Beauty; $\mathrm{RB}=$ Rainbow; $\mathrm{SQ}=$ Silver Queen; $\mathrm{AG}=$ Arboretum Giant; $\mathrm{BG}=\mathrm{Burgundy}$ Glow; $\mathrm{GTY}=\mathrm{Gaiety} ; \mathrm{CG}$ $=$ Catlin's Giant; GR = Green; ROY = Royalty; $\mathrm{SB}=$ Silver Beauty; MCR = Mini Crispa Red.

${ }^{\mathrm{y}}$ Mosaic; red, yellow spots; ringspots; oakleaf pattern.

${ }^{ }$Figures in parentheses $=$percentages of samples of that cultivar tested.

wTotal of samples with symptoms that tested negative for all viruses. 


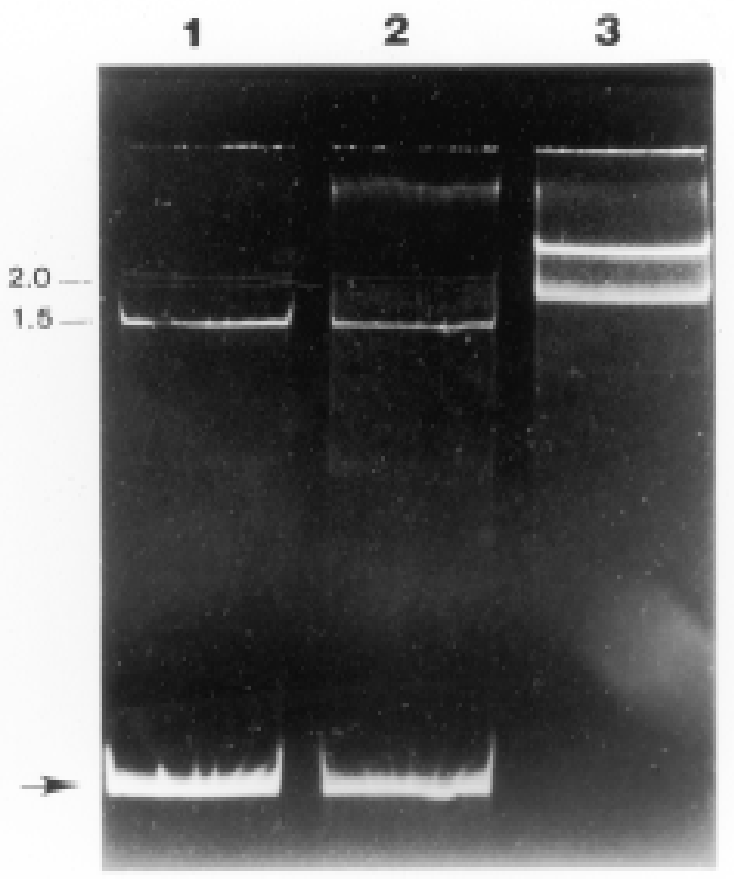

Fig. 2. Double-stranded ribonucleic acid analysis (dsRNA) banding patterns obtained from Lane 1: cucumber mosaic virus white-leaf isolate (CMV-WL); Lane 2: Ajuga reptans 'Royalty'; and Lane 3: tobacco mosiac virus (TMV) common strain. Numbers next to lane 1 indicate approximate dsRNA molecular weights $\left(2.0,1.5 \times 10^{6}\right)$. Arrow indicates double-stranded satRNA band.

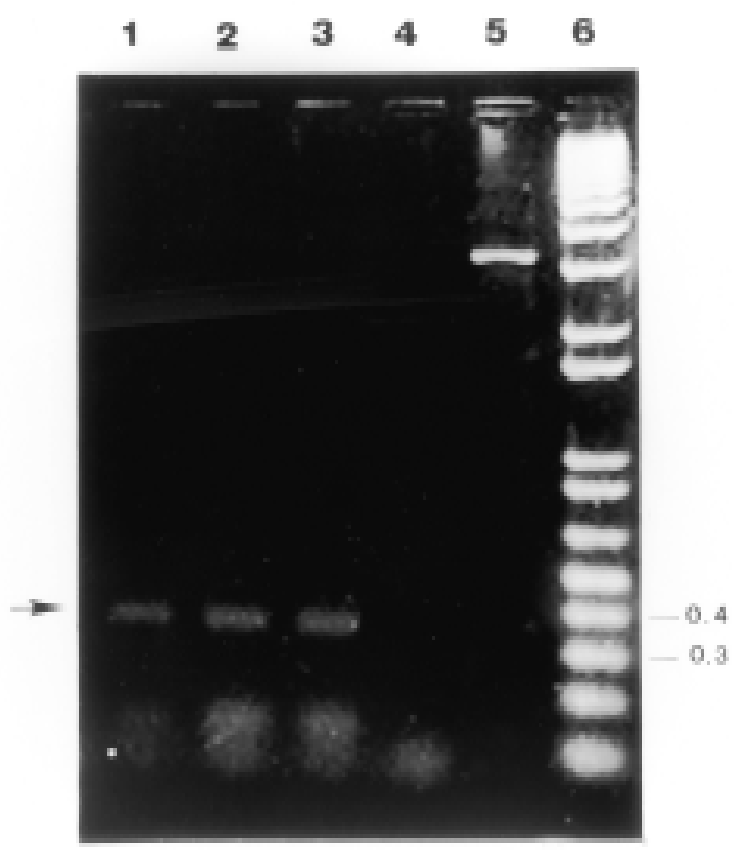

Fig. 4. Reverse transcription polymerase chain reaction (RT-PCR) analysis of Ajuga reptans 'Royalty' seedling samples using primers specific for cucumber mosaic virus (CMV) satellite RNAs. Lanes 1-2: A. reptans 'Royalty' seedling samples; Lane 3: CMV isolate from A. reptans 'Royalty' in N. tabacum 'Glurk' (positive control); Lane 4: doubledistilled water (negative control); Lane 5: (S)CARNA-5 cDNA marker (faint band between 0.3 and $0.4 \mathrm{~Kb}$ markers) digested from pSP65 plasmid (3.0 Kb band) with EcoRI; and Lane 6: $1 \mathrm{~Kb}$ Plus DNA markers. Arrow indicates PCR product between 0.3 and $0.4 \mathrm{~Kb}$ marker.

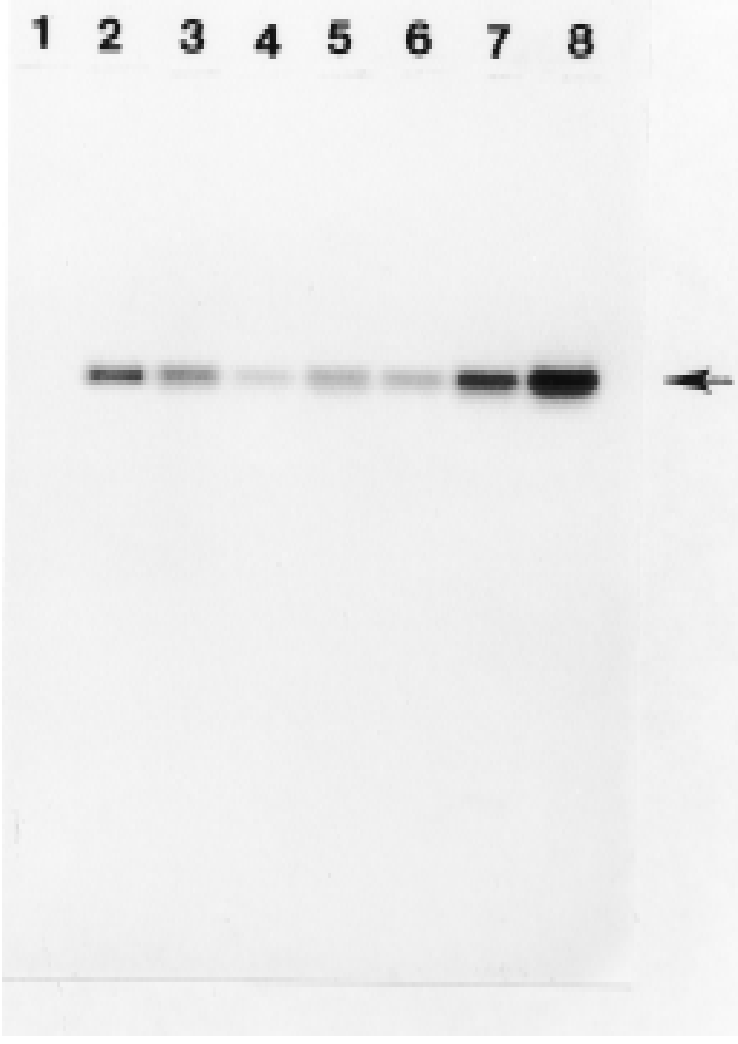

Fig. 3. Northern blot analysis of Ajuga reptans 'Royalty' samples using digoxigenin-labeled (S)CARNA5 cDNA; Lane 1: tobacco mosaic virus (TMV) common strain (negative control); Lane 2: unlabeled (S)CARNA-5 cDNA (positive control). Lanes 3-8: A. reptans 'Royalty' samples. Arrow indicates satRNA band. pattern, including satRNA. A 'Turk' inoculated with 'Royalty' sap and showing systemic line pattern/ringspots was used as inoculum to inoculate a series of 'Glurk' plants. The systemic line pattern and ringspot symptom developed on the 'Glurk' plants, and the symptomatic tissue was tested by ELISA for CMV, AMV, tobacco ringspot Nepovirus (TbRSV) and tomato ringspot Nepovirus (TRSV). All of the inoculated 'Glurk' samples were positive for AMV and negative for the other viruses.

\section{Discussion}

These ELISA results show that only CMV, AMV, and TSV were present in the cultivars of A. reptans tested. CMV was found in $11.0 \%$, $\mathrm{AMV}$ in $22.2 \%$, TSV in $3.7 \%$, and a mixture of CMV and AMV in $1.1 \%$ of the samples tested. When the data were broken down by cultivar, CMV was more prevalent in 'Royalty' and 'Rainbow'; AMV in 'Bronze Beauty', 'Burgundy Glow', and 'Green'; and TSV in 'Bronze Beauty' and 'Green' (Table 1).

Thirty-five (18.5\%) 'Bronze Beauty', one (2.9\%) 'Green', one (4.2\%) 'Gaiety', and one (4.2\%) 'Silver Queen' sample had elevated absorbance values for AMV, but these were not high enough to be considered true positives. The AMV often causes a symptomless infection in many of its hosts (Jaspars and Bos, 1980), and in tobacco AMV quickly reaches peak titre, but then declines to a very low level, which coincides with recovery from symp- 
toms (Jaspars and Bos, 1980; Ross, 1940). That this occurs in A. reptans as well is very likely, and the samples with elevated absorbance for AMV may represent cases where the virus titre is reduced. If these samples are actually AMV positive, the number of samples infected with AMV increases to $117 / 356(33 \%)$. There were also 13 (6.9\%) 'Bronze Beauty' and five (14.3\%) 'Green' samples with elevated but negative absorbance values for TSV, and one $(2.7 \%)$ 'Royalty' sample with an elevated but negative absorbance value for CMV.

Sixty-two of the 79 (78.5\%) samples positive for AMV, 30 of $39(77.0 \%)$ samples positive for CMV, and 11 of $13(85.0 \%)$ samples positive for TSV were asymptomatic (Table 1). Thirty-two (17\%) 'Bronze Beauty' and four $(57 \%)$ 'Catlin's Giant' samples were symptomatic but negative for all viruses (Table 1). Another 32 (17\%) 'Bronze Beauty' samples showed various symptoms, and had an elevated, but negative, absorbance value for AMV. Possible explanations for this could be that the virus titre was too low to detect or that there was an infection by another, still unidentified, virus.

The situation may be very different in 'Royalty', where 30 of 36 plants were asymptomatic, but 35 of $36(97.2 \%)$ were positive for $\mathrm{CMV}$, and one had a negative, but elevated, absorbance value. As indicated, a satRNA was associated with CMV in 'Royalty' and 'Rainbow' samples. An explanation for the high number of symptomless CMV infections in 'Royalty' could be a symptom-moderating effect of the satRNA. That there are two main satRNA phenotypes is generally accepted. Symptoms induced by the helper virus are either attenuated or exacerbated by the satRNA (Collmer and Howell, 1992). The satRNA is probably attenuating symptoms in the asymptomatic 'Royalty' plants.

None of the samples tested were positive for TAV, which can also act as the helper virus for CMV satRNAs (Collmer and Howell, 1992). In the case of the two 'Burgundy Glow' plants with a mixed infection by CMV and AMV, and where dssatRNA was detectable, this is the first time we have encountered satRNA in this cultivar. Previously we could detect CMV genomic dsRNAs, but never dssatRNA (Fisher and Nameth, unpublished). The results of the mechanical inoculations of tobacco using 'Royalty' and 'Rainbow' as inoculum sources indicate that AMV may also be prevalent in those cultivars.

The ELISA results obtained from the 'Royalty' seedlings grown from the seed of CMVinfected 'Royalty' plants suggest that CMV and AMV may be seed transmitted in this host as well. A more detailed study is required to determine if the seed is just surface-contaminated or if the embryo is infected. The mixed infection by CMV and AMV in two of the 16
'Royalty' seedlings tested is the first instance we have observed of these two viruses being detected together directly from 'Royalty' tissue. A possible explanation could be that the young tissue collected was actively growing, and this facilitated the replication of the AMV. The RT-PCR results confirmed that the satRNA was also present in all 16 CMV-infected 'Royalty' seedlings. Because there was very little tissue to work with, given the small size of the seedlings, RT-PCR was an excellent tool for detection of satRNA.

These results have several implications for the commercial perennial plant grower. First, since $A$. reptans is an herbaceous perennial, it can serve as a reservoir for $\mathrm{CMV}$ and its satRNA, AMV, and TSV. This becomes even more important when one takes into consideration how many asymptomatic A. reptans samples were positive for CMV, AMV or TSV (Table 1). Since all three of these viruses have an insect vector, there is a real possibility of virus spread from asymptomatic A. reptans plants or plantings to nearby perennial stock of the same and other species. Without symptoms to draw the grower's attention, all may appear well. The second implication for the grower is that since $A$. reptans is largely propagated vegetatively, infected but asymptomatic stock plants may be being propagated. This seems to be a likely scenario since we have been unable to locate any source of $A$. reptans 'Royalty' that is "virus- free". The striking coloration present in certain cultivars may be caused by viral infection. Yet a third implication may be derived from the presence of CMV satRNA in 'Royalty'. Although it appears not to cause severe disease in $A$. reptans, it may cause very different symptoms in other hosts. As mentioned previously, the CMVWL helper strain and satRNA can cause a white leaf syndrome in tomato, but a symptomless infection in tobacco (Gonsalves et al., 1982). A CMV satRNA is also responsible for a lethal necrosis disease of tomato (Kaper and Waterworth, 1977), so being aware of potential sources and reservoirs of both CMV and satRNA is important.

\section{Literature Cited}

Clark, M.F. and A.N. Adams. 1977. Characteristics of the microplate method of enzyme-linked immunosorbent assay for detection of plant viruses. J. Gen.Virol. 34:475-483.

Collmer, C.W. and S.H. Howell. 1992. Role of satellite RNA in the expression of symptoms caused by plant viruses. Annu. Rev. Phytopathol. 30:419-442.

Dodds, J.A.,T.J. Morris, and R.L. Jordan. 1984. Plant viral double-stranded RNA. Annu. Rev. Phytopathol. 22:151-168.

Edwardson, J.R. and R.G. Christie. 1991. Handbook of viruses infecting legumes. CRC Press, Boca Raton, Fla.

Fisher, J.R. and S.T. Nameth. 1997. Cucumber mosaic virus, tobacco streak virus, and cucum- ber mosaic virus satellite RNA associated with mosaic and ringspot symptoms in Ajuga reptans in Ohio. Plant Dis. 81(10):1214.

Francki, R.I.B., D.W. Mossop, and T. Hatta. 1979. Cucumber mosaic virus, p. 1-5. In: No. 213 (No. 1 revised) in CMI/AAB descriptions of plant viruses. Cmwlth. Mycol. Inst., Assn. Appl. Biologists, Kew, Surrey, England.

Fulton, R.W. 1985. Tobacco streak virus, p. 1-4. In: No. 307 (Nos. 44 and 106 revised) in CMI/AAB descriptions of plant viruses. Cmwlth. Mycol. Inst., Assn. Appl. Biologists, Kew, Surrey, England.

Garcia-Arenal, F., M. Zaitlin, and P. Palukaitis. 1987. Nucleotide sequence analysis of six satellite RNAs of cucumber mosaic virus: Primary sequence and secondary structure alterations do not correlate with differences in pathogenicity. Virology 158:339-347.

Gonsalves, D., R. Provvidenti, and M.C. Edwards. 1982. Tomato white leaf: The relation of an apparent satellite RNA and cucumber mosaic virus. Phytopathology 72:1533-1538.

Hidaka, S., K. Ishikawa, Y. Takanami, S. Kubo, and K.I. Miura. 1984.Complete nucleotide sequence of RNA 5 from cucumber mosaic virus (strain Y). FEBS Lett.174(1):38-42.

Hidaka, S., K. Hanada, K. Ishikawa, and K.I. Miura. 1988. Complete nucleotide sequence of two new satellite RNAs associated with cucumber mosaic virus. Virology 164:326-333.

Innis, M.A., D.H. Gelfand, J.J. Sninsky, and T.J. White (eds.). 1990. PCR protocols: A guide to methods and applications. Academic, San Diego.

Jaspars, E.M.J. and L. Bos. 1980. Alfalfa mosaic virus, p. 1-4. In: No. 229 (No. 46 revised) in $\mathrm{CMI} / \mathrm{AAB}$ descriptions of plant viruses. Cmwlth. Mycol. Inst., Assn. Appl. Biologists, Kew, Surrey, England.

Jordan, R.L., J.A. Dodds, and H.D. Ohr. 1983. Evidence for virus-like agents in avocado. Phytopathology 73:1130-1135.

Kaper, J.M. and H.E. Waterworth. 1977. Cucumber mosaic virus associated RNA 5: Causal agent for tomato necrosis. Science 196:429-431.

Kristensen, H.R. 1956. Virus diseases of cucumber in Denmark. Horticultura 10:161-172.

Kurath, G. and P. Palukaitis. 1987. Biological activity of T7 transcripts of a prototype clone and a sequence variant clone of a satellite RNA of cucumber mosaic virus. Virology 159:199-208.

Morris, T.J. and J.A. Dodds. 1979. Isolation and analysis of double stranded RNA from virusinfected plant and fungal tissue. Phytopathology 69:854-858.

Ross, F.A. 1940. The concentration of alfalfa mosaic virus in tobacco plants at different periods of time after inoculation. Phytopathology $31: 410-420$.

Sambrook, J., E.F. Frisch, and T. Maniatis. 1989 Molecular cloning: A laboratory manual. Cold Spring Harbor Lab. Press. 7.46-7.50.

Schroeder, W.T. and R. Provvidenti. 1972. Alfalfa mosaic virus in Ajuga reptans. Plant Dis. Rptr. $56: 285$.

Shukla, D.D. and K.H. Gough. 1983. Tobacco streak, broad bean wilt, cucumber mosaic, and alfalfa mosaic viruses associated with ring spot of Ajuga reptans in Australia. Plant Dis. 67:221-223.

Valverde, R.A., S.T. Nameth, and R.L. Jordan. 1990. Analysis of double-stranded RNA for plant virus diagnosis. Plant Dis. 74:255-258. 